\title{
PEMBELAJARAN DENGAN PENDEKATAN STUDENT CENTERED LEARNING (SCL) PADA SEKOLAH MINGGU
}

\author{
Wahju Astjarjo Rini \\ Universitas Kristen Indonesia \\ wahyuarini10862@gmail.com
}

\begin{abstract}
Abstrak
Tulisan ini bermaksud menawarkan sebuah alternatif pembelajaran di Sekolah Minggu melalui pendekatan Student Centered Learning (SCL). Model pendekatan ini merupakan pendekatan pembelajaran yang memberdayakan peserta didik menjadi pusat (center) selama proses pembelajaran berlangsung. Sekolah Minggu merupakan salah satu media pembelajaran untuk mengenalkan anak kepada Tuhan dan beriman kepada-Nya. Masa anak-anak merupaka periode yang ideal bagi seorang anak untuk tetap beriman kepada Tuhan sampai dengan dewasa. Riset yang dilakukan oleh Barna Research Group (BRG) pada tahun 2001, 61\% memperlihatkan bahwa orang dewasa yang saat ini setia beribadah di gereja adalah mereka yang dahulu dengan setia mengikuti Sekolah Minggu. Adapun metode yang digunakan dalam pengembangan artikel ini adalah metode studi pustaka, yaitu dengan membaca tulisan-tulisan dari berbagai sumber yang relevan. Hasil yang dapat diperoleh dari penulisan artikel ini adalah, ditengah-tengah perkembangan jaman modern ini, pendekatan SCL pada Sekolah Minggu dapat diterapkan, melalui pemahaman kerativitas guru terhadap setiap tahapan dari aspek kognitif, afektif dan psikomotorik. Ketiga aspek ini dapat disebut sebagai pendekatan yang berpusat pada murid untuk dapat mengenalkan ketaatan kepada Allah, memiliki iman intuitif-projektif, yang dengannya anak dapat memahami kasih, rasa aman, disiplin, sukacita dan penyembahan kepada Tuhan. Selanjutnya adalah iman, pada masa akhir kanak-kanak, ketika seorang anak biasanya memercayai sesuatu yang dipercayai orang tuanya, belajar secara aktif untuk membagikan pengalaman serta dialog, atau bermain peran dalam bentuk sandiwara bahkan menjadi reporter. Selanjutnya dari ranah kognitif, yakni seorang anak memasuki ranah analisis, ketika ia menerima informasi yang dibagikan oleh teman-temannya dalam bentuk cerita sederhana, dan sintesis, serta evaluatif. Secara afektif diarahkan ke sikap dimana murid siap menerima nilai-nilai yang diyakininya, serta murid mulai menyikapi karakterisasi nilai yang akan dijadikan bagian nilai-nilai dari pola hidupnya. Dari aspek psikomotorik, anak dapat diarahkan kepada gerakan presisi, yakni gerakan yang tepat atau akurat.
\end{abstract}

Kata kunci: Student Centered Learning (SCL), kognitif, afektif, psikomotorik. 


\section{A. Pendahuluan}

Dalam sebuah Seminar Kepemimpinan Kristen, disampaikan bahwa usia 4 sampai dengan 14 tahun merupakan usia yang penting bagi seorang anak, karena pada usia tersebut anak-anak mendapat kesempatan bersekolah minggu. Data ini berdasarkan riset yang dilakukan oleh Barna Research Group (BRG) pada tahun 2001, $61 \%$ orang dewasa yang saat ini ke gereja adalah dahulu yang mengikuti sekolah minggu. Ketika seorang anak menerima Yesus di usia 7-9 tahun, ia akan menjadi pengikut Kristus seumur hidup. Untuk itu dibutuhkan guru sekolah minggu yang mumpuni, dan strategi pembelajaran yang tepat agar tumbuh generasi yang baik pada masa 20 tahun yang akan datang.

Pelopor Sekolah Minggu adalah Robert Raikers bersama pendeta Thomas Stock tahun 1874. Bermula dari Revolusi Industri, yakni setelah tenaga manusia digantikan oleh mesin uap, hal ini menghasilkan efek samping terjadinya peningkatan kemiskinan di Inggris. Selanjutnya terjadi urbanisasi dan bekerja sebagai buruh pabrik, upah yang diterima sangat rendah, salah satu efeknya menimbulkan tidak kejahatan mulai ringan sampai berat. Generasi muda perlu diselamatkan, anak-anak dari keluarga ini mendapat bimbingan iman Kristen dan keterampilan membaca dan menulis, setelah 28 tahun pendirian, pertumbuhannya sangat pesat sampai sekitar lebih dari 400.000 orang. Bertolak dari situasi ini, muncullah upaya menyelamatkan generasi muda agar tumbuh lebih baik adalah melalui Sekolah Minggu. Hal ini merupakan upaya pemeliharaan dalam hal

1 Boehlke, Robert R. Sejarah Perkembangan Pikiran dan Praktek Pendidikan Agama Kristen (Jakarta: BPK Gunung Mulia. 2016), 397-421. memperkuat pendirian karakter generasi muda agar bertumbuh secara sehat. Dalam perkembangannya, Sekolah Minggu menjadi pilar pendidikan karakter di dalam Gereja, yang melaluinya pembekalan bagi warga dilakukan sejak dini dengan pengetahuan yang baik dan benar dalam memahami kehendak Tuhan melalui firman-Nya, semenjak anak-anak agar mereka dapat bertumbuh dalam pemahaman iman yang benar tentang Yesus Kristus. ${ }^{2}$

Secara umum dapat dikatakan, pembangunan karakter anak ditentukan oleh pendidikan, salah satunya melalui Sekolah Minggu. Pada dasarnya seorang anak senang meniru segala hal yang dilakukan oleh sosok yang mengajarnya. Melalui wadah gereja, para guru sekolah minggu adalah pendidik yang mengenalkan Tuhan sebagaimana yang tertulis dalam Amsal 1:7a, sejak anakanak untuk memiliki hikmat dengan hormat dan gentar kepada Tuhan. Dunia tempat kehidupan saat ini di penuhi dengan tantangan yang rumit dan kompleks. Tumbuh kembang anak-anak yang takut akan Tuhan di masa kini tidak mudah, dan oleh sebab itulah keteladanan sangat berperan dalam pembentukan karakter anak, mengingat dibutuhkan karakter yang kuat untuk menjalani kehidupan, sehingga mampu mengatasi persoalan yang dihadapi di masa depan sebagaimana dikatakan dalam Amsal 22:6, agar anak muda dididik menurut jalan Tuhan, agar supaya pada masa tua tetap pada jalan Tuhan. Gereja sesuai dengan Amanat Agung Tuhan yang tertera di Matius 28:19-20 merupakan wakil dari Kerajaan Allah di dunia ini dan diperintahkan untuk membawa berita Injil untuk semua manusia di bumi. Gereja sebagai lembaga yang 
mengantarkan anak-anak untuk menjadi anggota, selanjutnya bertumbuh menjadi umat yang beriman, serta menjadi anakanak Allah. Sejak permulaan gereja telah menjadi masyarakat yang mengajar. ${ }^{3}$

Situasi dunia dewasa ini ditandai oleh pelbagai ragam perkembangan teknologi, ilmu pengetahuan dan informasi yang kian tak terbendung merebak di segala sendi kehidupan manusia. Gelombang globalisasi yang kian mendera dan tidak terbendung dan merasuk ke dalam sendi-sendi kehidupan masyarakat, menjadi tantangan tersendiri dalam merumuskan strategi pembelajaran di sekolah minggu di gereja. Didalam situasi seperti ini, praktek iman sangat penting pada pembentukan nilai dan watak Kristen kepada anak-anak, agar melahirkan generasi yang berkarakter Kristus, hidup kudus dan takut akan Tuhan sebagaimana dalam (Kol. 2:3). Pendidikan karakter sangat diperlukan ditengah maraknya persaingan di era global, karena karakter seseorang menentukan kesuksesan individu . Tuntutan kualitas sumber daya manusia membutuhkan pembangunan kualitas karakter yang baik, dalam hal ini peran guru Kristen sangat memberikan kontribusi terhadap kebutuhan tersebut.

Anak-anak mendapat perhatian penting, sebagaimana yang tertulis dalam (Mat. 19:14), Yesus memberikan waktu untuk mengajar anak-anak. Meneladani Yesus Sang Guru Agung (Luk. 18:18-19 ), Alkitab mencatat Yesus sebagai Guru yang baik. Tuhan Yesus dipanggil sebagai Guru dalam (Luk. 7:40, Luk. 8:24, Luk. 10:25, Luk. 12:13). Gereja menempatkan anak-anak sebagai golongan utama, dimana abd ini seriing disebut abad anak-anak. Penting bagi guru sekolah minggu untuk memiliki

\footnotetext{
${ }^{3}$ Cully, Iris V. Dinamika Pendidikan Kristen
} (Jakarta: BPK Gunung Mulia, 2011), 1-3. pendekatan pembelajaran yang berpusat pada murid dalam mengenalkan Yesus dan mengajarkan nilai-nilai kebenaran Firman Tuhan untuk membentuk prilaku yang baik serta tumbuh menjadi manusia baru sehingga kelak dapat menjadi agent of development dan agent of change dalam peradaban. Hal tersebut adalah sebagai wujud tindakan preventif dalam mengatasi berbagai persoalan dalam membangun karakter yang berpusat pada Yesus. $^{4}$

\section{B. Pembahasan}

1. Tinjauan Teoretis atas Pendekatan Student Centered Learning (SCL).

Seorang Guru Sekolah Minggu pada masa kini perlu menyesuaikan aktivitas pembelajaran dengan mengadopsi pendekatan Student Centered Learning (SCL). Pendekatan Student Center Learning (SCL) ini merupakan pendekatan pembelajaran yang memberdayakan peserta didik sebagai pusat (center) selama proses pembelajaran berlangsung. Pendekatan ini muncul sebagai alternatif untuk menjebatani ketidaksesuaian dalam pendekatan Teacher Centered Learning (TCL).

Kegiatan belajar mengajar di dalam kelas sekarang ini tidak hanya mempergunakan model pembelajaran satu arah, yakni guru menerangkan dan murid mendengarkan tetapi pembelajaran yang efektif harus melibatkan murid dalam proses pembelajaran. Pendekatan Student Center Learning (SCL) ini merupakan pendekatan pembelajaran yang memberdayakan peserta didik menjadi pusat (center) selama proses

4 Homrighausen, Enklaar. Pendidikan Agama Kristen. (Jakarta: BPK Gunung Mulia, 2015), 117-118. 
pembelajaran berlangsung. ${ }^{5}$ Pelaku utama pengajaran dan perencanaan student centered adalah murid dan bukan guru. Dalam sebuah studi, persepsi murid terhadap lingkungan pembelajaran dan hubungan interpersonal positif dengan guru sebagai faktor paling penting yang memperkuat motivasi dan prestasi murid. ${ }^{6}$ Pembelajaran dengan pendekatan SCL, murid dilatih membentuk konsep diri positif, terbuka, sabar dan kreatif serta berproses dalam pengalaman. ${ }^{7}$

Pengaruh John Dewey (1859 1952) yang mempromosikan pendidikan progresif melahirkan student centered education merupakan reaksi terhadap pendidikan yang menekankan metode formal yang ketat, pembelajaran instruksional, dan teacher oriented. Menurut Allan Ornstein, kaum progresif sepakat mempertentangkan praksis pendidikan yang mempermasalahkan hal-hal berikut: guru yang otoriter, pembelajaran dengan metode yang mengandalkan instruksi, pembelajaran yang menggunakan instruksi dalam buku teks. Pendekatan ini muncul sebagai alternatif untuk menjawab permasalahan ketidaksesuaian pendekatan Teacher Centered Learning (TCL). Disini menunjukkan fungsi guru adalah sebagai fasilitator, pengetahuan bukan sesuatu yang sudah jadi dan tinggal ditransfer, melainkan sebuah hasil konstruksi dengan si pembelajar, dimana si pembelajar dilibatkan secara aktif, dan tidak hanya diampaikan dengan ceramah, namun dengan diskusi dan partisipasi lainnya. ${ }^{8}$

${ }^{5}$ Isjoni \& Firdaus, LN. Pembelajaran Terkini (Yogyakarta: Pustaka Pelajar,2008), 60-61.

6 Khoe Yao Tung. Pembelajaran dan Perkembangan Belajar (Jakarta: Indeks, 2015),312.

${ }^{7}$ Evelin, Hartini. Teori Belajar dan Pembelajaran (Bogor: Ghalia Indonesia, 2014), 76.

${ }^{8}$ Khoe Yao Tung. Filsafat Pendidikan Kristen (Yogyakarta: Andi, 2013),101.
Pada pendekatan SCL, murid memiliki hasrat dasar dengan lingkungan sekitarnya. Murid sebagai konstruktor, penemu dan mentransformasi pengetahuan. ${ }^{9}$ Ciri khas dari metode pembelajaran SCL sesuai unsurnya dapat dirinci sebagai berikut: guru, berperan sebagai fasilitator dan motivator; murid, harus menunjukkan kinerja, yang bersifat kreatif yang mengintergrasikan kemampuan kognitif, psikomotorik dan afeksi secara utuh; proses interaksinya, menitikberatkan pada "method of inquiry and discovery"; sumber belajarnya, bersifat multi demensi, artinya bisa diperoleh dari mana saja; dan lingkungan belajarnya, harus terancang dan kontekstual. ${ }^{10} \quad$ Kemampuan menjalankan fungsi dan peran guru sebagai fasilitator dan motivator dalam proses pembelajaran yang berpusat pada murid akan mendorong munculnya murid yang kreatif. Di dalam proses pembelajaran SCL, guru memiliki peran yang penting dalam pelaksanaan SCL, yaitu bertindak sebagai fasilitator dalam proses pembelajaran. ${ }^{11}$

Peran dari guru dalam memberikan arahan kepada murid agar dapat belajar, dapat diukur hasil belajarnya para murid berdasarkan tiga aspek yakni kognitif, afektif dan psikomotorik. Taksonomi menurut Bloom terdiri dari sasaran pendidikan dalam tiga domain yaitu kognitif, afektif dan psikomotor. ${ }^{12}$ Beberapa kemampuan dari aspek kognitif adalah ${ }^{13}$ :

${ }^{9}$ Khoe Yao Tung. Menuju Sekolah Impian Masa Kini (Yogyakarta: Yayasan Andi, 2015), 269.

10 Khoe Yao Tung. Pembelajaran dan Perkembangan Belajar (Jakarta: Indeks, 2015), 313.

${ }^{11}$ Ibid.

12 Khoe Yau Tung. Desain Instruksional (Yogyakarta: Andi, 2016), 41-43.

13 ibid 
1. Knowledge, mengingat, menghafal informasi, pengetahuan

2. Comprehension, memahami informasi dan dapat menerangkan dengan kalimat sendiri, menginterpretasikan

3. Aplication, menggunakan pengetahuan untuk memecahkan masalah dalam kehidupan keseharian.

4. Analysis, memecahkan informasi kompleks menjadi bagian-bagian kecil dan mengaitkan informasi dengan informasi lain, menjabarkan suatu konsep.

5. Syntesis, mengombinasikan elemen-elemen dan menciptakan informasi baru, menggabungkan bagian-bagian konsep menjadi suatu konsep utuh.

6. Evaluation, membuat penilaian dan keputusan, membandingkan nilai-nilai, ide, metode dsb.

Domain afektif, terdiri dari lima objektif yaitu ${ }^{14}$ :

1. Receiving - Penerimaan, sadar akan adanya suatu nilai, ingin menerima nilai.

2. Responding - Respons aktif berpartisipasi.

3. Valuing - Penilaian, menerima nilai-nilai, tunduk pada nilai-nilai tertentu.

4. Organizing - Penataan, menghubung-hubungkan nilainilai yang diyakininya
5. Characterizing - Karakterisasi nilai yang akan dijadikan bagian nilai-nilai dari pola hidupnya.

Domain psikomotorik, terdiri dari lima kategori yaitu ${ }^{15}$ :

1. Imitasi - meniru gerakan yang dilakukan oleh orang lain. Contoh: murid meniru gerakan bola gurunya.

2. Manipulasi - melakukan gerakan berbeda dengan yang diajarkan. Contoh: murid melakukan gerakan menendang bola dengan gaya sendiri, tidak lagi persis yang dicontohkan.

3. Presisi-melakukan gerakan yang tepat atau akurat. Contoh: murid menendang bola lebih terarah dan tepat sasaran.

4. Artikulasi - memberikan sentuhan seni dengan menggabungkan beberapa hal yang hasilnya sebuah harmoni. Contoh: murid menendang bola indah dengan gerakan melengkung (gerakan "pisang").

5. Naturalisasi - gerakan yang berkualitas menjadi bagian dari dirinya dan ketika dilakukan terjadi secara reflek. Contoh: murid sudah bisa menendang bola secara terarah, akurat dan indah seperti halnya seorang pesepakbola profesional. 
Gambar 3

Domain Kognitif Taxonomy Bloom

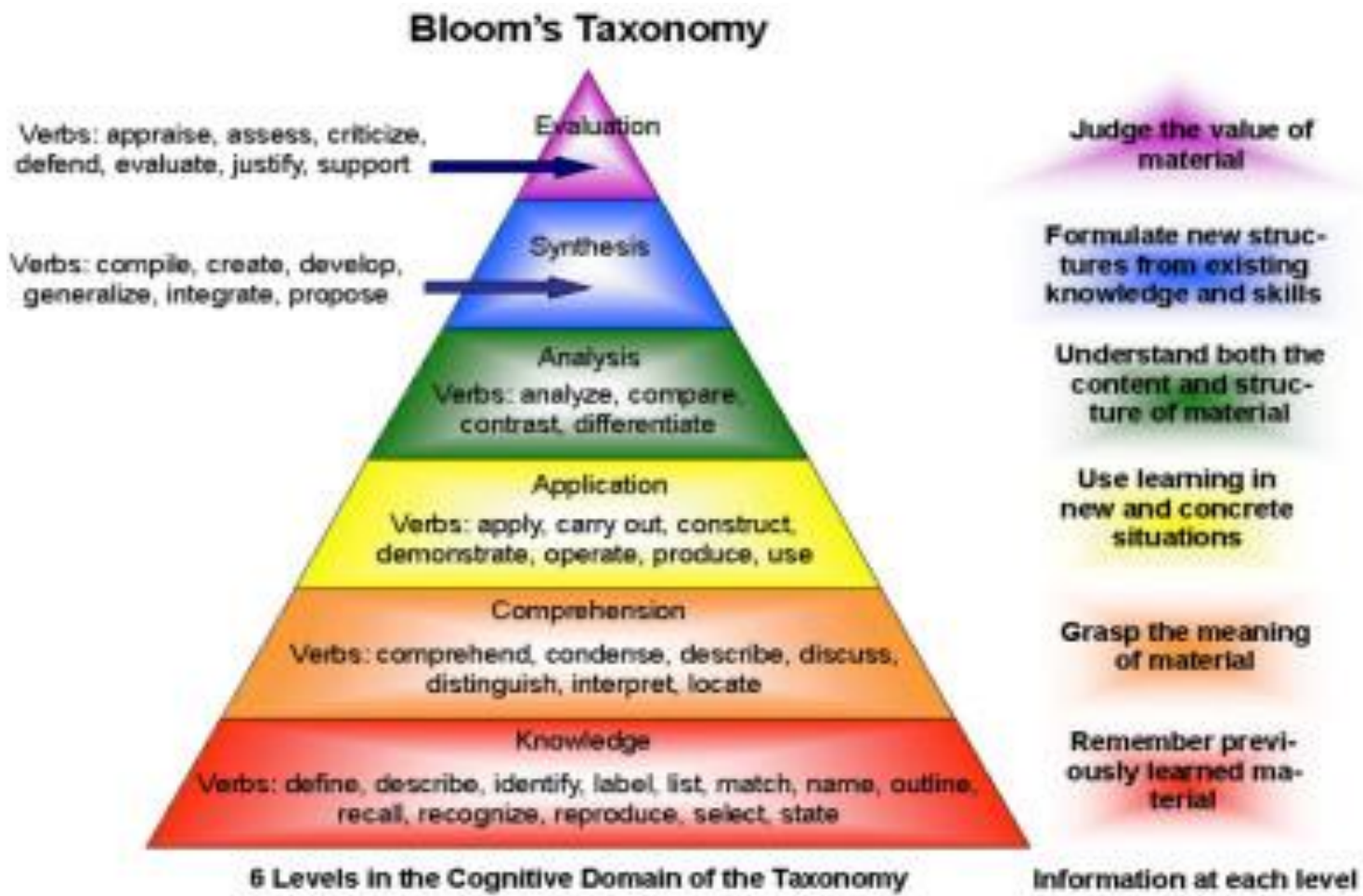

Gambar 3. Domain Kognitif Taxonomy Bloom $^{1}$

2. Student Centered Learning (SCL) pada Sekolah Minggu.

Pembelajaran merupakan seperangkat tindakan yang dirancang dalam mendukung proses belajar agar mencapai hasil melalui respon dari murid. ${ }^{2}$ Pembelajaran sebagai proses kegiatan belajar mengajar yang dilakukan oleh guru kepada murid untuk mencapai tujuan yang dirumuskan. Dalam pembelajaran pendekatan SCL perlu suasana kreatif dan menyenangkan, juga pembelajaran mengingat, menghafal dan mengulang adalah penting, seperti perintah Tuhan dalam Ulangan 6:6. Alkitab menyebutkan bahwa guru harus

1 https://insightsineducation.info/2016/02/ diunduh 12 Januari 2019

${ }^{2}$ Evelin, Hartini. Teori Belajar dan Pembelajaran (Bogor: Ghalia Indonesia, 2014),12-13. mampu menyenangkan dalam belajar (Ams. 7:22). ${ }^{3}$

Sekolah Minggu adalah sebuah kegiatan peribadahan yang dikhususkan bagi anak dalam Gereja sebagai pemeliharaan hidup iman kerohanian dengan Tuhan. Guru pengajar Sekolah Minggu sebagai pribadi yang inspiratif, sehingga mampu melaksanakan perannya dengan baik, yaitu dapat membangkitkan belajar yang kondusif, serta dapat mengatasi masalah saat murid mengalami kesulitan dalam proses pembelajaran. Kreativitas guru dapat berkembang dengan cara belajar dari sikap kreatif sang Guru Agung Tuhan Yesus saat mengajar para murid sebagaimana tertulis pada empat Injil, selanjutnya berani membuka diri untuk ide-ide yang

3 Khoe Yao Tung. Menuju Sekolah Kristen Impian Masa Kini (Yogyakarta: Yayasan Andi, 2015), 269-270. 
baru, serta memupuk rasa ingin tahu dan terus belajar menggali kebenaran. ${ }^{4}$

Guru Sekolah Minggu dengan pendekatan SCL dapat menjadikan pembelajaran secara kreatif dengan mengoptimalkan aspek Multiple Intelligences yang dimiliki oleh murid. Dalam setiap minggu dapat secara berganti selain menggunakan kecerdasan linguistik untuk berceritera, namun dapat dikombinasi dengan menggunakan angka untuk mengembangkan kemampuan kecerdasan logis matematis. Selanjutnya juga dapat menggunakan alat bantu visual dan gambar, warna juga ruang dan bangun. Menggunakan kecerdasan musikal dengan menyertakan lagu, musik. Menggunakan kecerdasan kinestetik dengan melibatkan anggota tubuh dan gerakan supaya aktif. Melibatkan murid untuk berbagi atau sharing, juga dapat dengan kegiatan kelompok. Menggunakan kecerdasan intrapersonal untuk mengungkapkan pengalaman pribadi, serta menggunakan kecerdasan naturalis dengan bersentuhan langsung ke alam, salah satunya untuk mengenal hewan dan tumbuh-tumbuhan. ${ }^{5}$ Pendekatan SCL adalah menekankan pada aktive learning, yakni untuk mengoptimalkan penggunaan semua keunggulan yang dimiliki murid, untuk berperan secara aktif. Melalui pendekatan Multiple Intelligences/kecerdasan majemuk yang dimiliki setiap murid, maka akan melahirkan variasi dan beragam pengalaman yang didapatkan dari setiap murid, selanjutnya dikombinasikan dengan tujuan pembelajaran yang menyentuh aspek kognitif, afektif maupun psikomotorik,

\footnotetext{
4 Amy Iwani. Belajar dari Sang Guru Agung Sebagai Kurikulum Hidup (Surabaya: MPK, 2016), 176-177.

${ }^{5}$ Meilania. Creative Teaching di Sekolah Minggu (Yogyakarta: Gloria Gaffa, 2015), 15-19.
}

sehingga suasana pembelajaran menjadi aktif. $^{6}$

Murid Sekolah Minggu dalam perkembangannya memiliki kehidupan yang tidak statis, tetapi dinamis. Maria Montessori ahli pendidikan anak, menekankan anak belajar melalui lingkungannya, dengan seminimal mungkin mendapatkan intervensi dari orang yang lebih dewasa. ${ }^{7}$

1) Periodisasi berdasarkan Biologis Montessori, terdapat empat periode perkembangan yaitu: a.) Periode I $(0,0-7,0)$ merupakan periode penerimaan, dimana kepekaan motoris dan panca indera berkembang. b.) Periode II (7,0 - 12), merupakan periode rencana abstrak, disini anak-anak sangat membutuhkan pendidik, oleh karena sudah mulai peka terhadap perasaan baik, buruk, moral dst. c.) Periode III (12,0 18,0) merupakan periode penemuan diri dan kepekaan bersosialisasi. Dalam periode ini diperlukan penguatan kepribadian. d.) Periode IV (18,0 --) merupakan periode pendidikan tinggi, disini berperan untuk ikut terlibat dalam kepentingan dunia. ${ }^{8}$ Johan Heinrich Peztalozzi (1746-1827) menyatakan bahwa "Anak akan belajar ketika mereka siap belajar", terdapat lima prinsip utama dalam mengarahkan anak yang beriman dan bergantung pada Tuhan: 1.) Kepercayaan kepada Allah. 2.) Alam sebagai pedoman. 3.) Tuhan menyelamatkan manusia, juru selamat dunia. 4.) Jati diri manusia. 5.) Pengalaman beriman secara pribadi. Dilihat dari sisi usia anak Sekolah Minggu, implementasi SCL dapat mengakomodasi kesiapan anak untuk merangsang kepekaan motoris untuk usia

\footnotetext{
${ }^{6}$ Evelin, Hartini. Teori Belajar dan Pembelajaran (Bogor: Ghalia Indonesia, 2014), 106.

7 Sumadi. Psikologi Pendidikan (Jakarta: Raja Grafindo Persada, 2014), 185-189.

${ }^{8}$ Ibid
} 
3-7 tahun dan kepekaan terhadap moral, dimana menurut model perkembangan moral oleh Lowrence Kohlberg pada kisaran usia tersebut masuk pada tingkat prekonvensional, pada usia ini anak dapat dikenalkan tentang ketaatan kepada Allah, dimana hal ini juga seiring dengan Heinrich Peztalozzi, yaitu Kepercayaan kepada Allah. ${ }^{9}$ Dari sisi perkembangan iman, menurut James Fowler ${ }^{10}$ kepercayaan kepada Allah adalah iman intuitif-projektif. Anak-anak sampai tujuh tahun mencerminkan iman yang terlihat jelas dari orang tuanya. Pendekatan SCL membawa pada anakanak untuk memahami kasih, rasa aman, disiplin, sukacita dan penyembahan. Melalui keteladanan dari guru, mulai mengembangkan kesadaran dan konsep tentang Allah, Yesus; mengembangkan sikap terhadap Allah, Yesus, gereja, diri sendiri dan Alkitab serta mengembangkan konsep tentang benar dan salah.

Pendekatan SCL dalam aspek kognitif dikategorikan dalam ranah knowledge, yakni mengingat, menghafal informasi, pengetahuan, dan Comprehension, yakni memahami informasi dan dapat menerangkan dengan kalimat sendiri, serta aplication, yakni mengaplikasikan arti ketaatan. Secara afektif, anak memasuki ranah penerimaan (receiving) yaitu sadar akan adanya suatu nilai, ia ingin menerima nilai dan membesarkan respon aktif (responding) yaitu berpartisipasi. Sebagai penerapan: dapat memperkenalkan tentang benda, nama dan jenis binatang. Guru dapat menyediakan berbagai macam bentuk

9 Pazmino, Robert W. Fondasi Pendidikan Kristen (Jakarta: BPK Gunung Mulia, 2012), 289-290.

${ }^{10}$ Ibid 297-300.

${ }^{11}$ Nyoman, Olga. Psikologi Pendidikan I (Jakarta: Erlangga, 2014), 96. benda dalam beberapa bentuk bulat, segi tiga, segi empat dan panjang dalam ukuran yang berbeda. ${ }^{11}$ Jean Piaget $^{12}$ dalam The Psichology of the Child (1966) mengatakan bahwa, tahapan cognitive learning development pada usia 0-2 tahun adalah sensori motorik dengan gerakan halus, sedangkan usia 2-7 tahun pra operasional, dimana anak sudah mulai dapat menyusun benda dengan benar.

Secara afektif pada kisaran usia 27 tahun sudah tumbuh perkembangan sosial, memiliki perasaan saling menyayangi dan mempunyai sifat kooperatif, anak sudah belajar tentang relasi dengan saudara kandung, orang tua, keluarga besar, teman serta mampu untuk berkomunikasi, serta memiliki kesadaran tentang identitas gender. ${ }^{13}$ Secara psikomotorik, ranah imitasi yaitu meniru gerakan yang dilakukan oleh orang lain dan manipulasi yaitu melakukan gerakan berbeda dengan yang diajarkan, kreatif dengan gayanya sendiri. Pandangan ini sejalan dengan Friederich Froebel (17821852) tokoh pendidikan anak, yang mengenalkan Froebel Gift dalam menggunakan benda/alat/simbol untuk melatih motorik. ${ }^{14}$

Setelah memahami periodisasi perkembangan, khususnya bagi anak Sekolah Minggu, pada periode kedua yaitu usia 7-12 tahun, seorang guru dapat mengajar secara kreatif dengan mendorong murid belajar secara aktif untuk membagikan pengalaman serta dialog, atau dengan bermain peran dalam bentuk sandiwara bahkan menjadi reporter. Secara perkembangan iman,

12 Khoe Yao Tung. Pembelajaran dan Perkembangan Belajar (Jakarta: Indeks, 2015), 42-44.

${ }^{13}$ Nyoman, Olga. Psikologi Pendidikan I (Jakarta: Erlangga, 2014), 111-114

14 Khoe Yao Tung. Pembelajaran dan Perkembangan Belajar (Jakarta: Indeks, 2015), 42-44. 
menurut James Fowler ${ }^{15}$ adalah iman mythic-literal, dimana pada masa akhir kanak-kanak seorang anak biasanya mempercayai sesuatu yang dipercayai orang tuanya dan tidak pernah yang lain. Implementasi pendekatan pembelajaran SCL dapat dikembangkan untuk mendorong murid secara kognitif, masuk ke ranah analisis, tentang informasi yang dibagikan oleh teman-temannya dalam bentuk cerita sederhana, dan syntesis, yaitu mengombinasikan secara sederhana terhadap pengalaman dari dirinya serta evaluation, yaitu membuat penilaian terhadap pengalaman yang diceritakan tersebut. Secara afektif adalah diarahkan ke sikap valuing, murid siap menerima nilai-nilai, tunduk pada nilai-nilai tertentu; organizing, yakni murid dapat menata dan menghubung-hubungkan nilai-nilai yang diyakininya, serta characterizing yaitu murid mulai menyikapi karakterisasi nilai yang akan dijadikan bagian nilai-nilai dari pola hidupnya. Secara psikomotorik dapat diarahkan melakukan gerakan presisi, melakukan gerakan yang tepat atau akurat; artikulasi, yaitu memberikan sentuhan seni dengan menggabungkan beberapa hal yang hasilnya sebuah harmoni. Jean Piaget tokoh pendidikan anak menekankan pada usia 7-11 tahun masuk pada tahap operasional konkrit, dimana anak sudah dapat melakukan penalaran secara logis untuk memahami kesimpulan. Pada usia ini, murid membutuhkan keteladanan, role model yang memberikan contoh, mulai dari kejujuran serta kekudusan hidup dalam standar kebenaran Tuhan. ${ }^{16}$ Jean Piaget

\footnotetext{
${ }^{15}$ Meilania. Creative Teaching di Sekolah Minggu (Yogyakarta: Gloria Gaffa, 2015), 23-39.

16 Khoe Yao Tung. Pembelajaran dan Perkembangan Belajar (Jakarta: Indeks, 2015), 42-44.

17 Groome, Thimas H. Christian Religious Education (Jakarta: BPK Gunung Mulia, 2011), 362-364.
}

menyatakan pada periode ini, seorang anak mampu menginternalisasi tindakan, serta membentuk penalaran yang logis untuk melihat hubungan sebab akibat dengan melakukan refleksi diri. ${ }^{17}$ Dalam pemahaman konsep tentang karakter, seperti perasaan dan emosi, dapat dilakukan dengan bermain peran oleh murid, kemudian mendiskusikan bagaimana perasaan dan emosi yang sesuai dengan diperankannya. ${ }^{18}$

Sesuai model perkembangan moral oleh Kohlberg pada kisaran usia tersebut masuk pada tingkat konvensional (usia 7-12), dimana terdapat orientasi interpersonal dan konkordasi, misalnya tentang apa yang orang lain harapkan dari saya? Bagaimanakah saya dapat menyenangkan orang tua, supaya saya disebut sebagai anak yang baik? ${ }^{19}$ Dalam hal ini, seorang anak sudah mampu untuk bersikap, dengan demikian pendekatan SCL dapat berjalan optimal.

2) Periodisasi berdasarkan Didaktis, menurut Johann Amos Comenius sesuai dengan perkembangan jiwa anak: a.) Scola materna (sekolah ibu) untuk anak-anak usia 0,0-6,0. b.) Scola vernacula (sekolah bahasa ibu) untuk anak-anak usia 6,0-12. c.) Scola latina (sekolah latin) untuk anak-anak umur 12-18. d.) Academia (akademi) untuk anak-anak usia $18-24 .{ }^{20}$ Dalam periodeisasi didaktis, dapat melakukan pembelajaran pendekatan SCL dengan model Quantum teaching, yaitu menciptakan lingkungan belajar yang efektif, melalui interaksi yang intensdif, guru menciptakan hubungan emosional

${ }^{18}$ Nyoman, Olga. Psikologi Pendidikan I (Jakarta: Erlangga, 2014), 96-97.

19 Pazmino, Robert W. Fondasi Pendidikan Kristen (Jakarta: BPK Gunung Mulia, 2012), 289-290.

${ }^{20}$ Sumadi, S. Psikologi Pendidikan (Jakarta: Raja Grafindo Persada, 2014), 190-191. 


\section{4 | Shanan Jurnal Pendidikan Agama Kristen Vol. 3 No. 1 Oktober 2019}

yang baik dengan murid. Guru masuk kedalam dunia pemikiran sang murid, mengingat prinsip dari pembelajaran tersebut adalah membantu murid menumbuhkan minat belajar dengan semangat dengan menekankan pentingnya bahasa tubuh seperti kontak mata, senyum, menghargai usaha murid dengan pengakuan dan menumbuhkan kepercayaan diri. ${ }^{21}$ Model quantum teaching memiliki kemiripan dengan sebuah orkestra, yaitu dalam segi konteks dan isi. Konteks terdiri dari empat aspek yaitu suasana yang memberdayakan, landasan yang kukuh, lingkungan yang mendukung dan rancangan yang dinamis. Sedangkan isi, merupakan keterampilan penyampaian dengan penyajian yang prima, luwes, terampil dalam belajar mengjar dan mendorong pada keterampilan kehidupan. ${ }^{22}$ Dari aspek perkembangan iman, menurut James Fowler $^{23}$ pada aspek ini murid sudah dapat menerima dan mengakui Yesus Kristus sebagai juru selamat dan Tuhan; bertumbuh dalam kesadaran akan kasih dan tanggungjawab kristiani dalam hubungan dengan orang lain; terus membangun konsep tentang realitasrealitas kristiani yang mendasar; mempelajari pengajaran Alkitab mendasar yang menunjang iman pribadi dan kehidupan Kristen sehari-hari (Ams. 9:9)

3) Periodisasi berdasar Psikologis, menurut PH. Kohnstamm terdapat empat periodisasi yaitu: a.) usia 0,0- 2,0 sebagai masa vital. b.) usia 2,07,0 sebagai masa estetis. c.) usia 7,0 - 13

${ }^{21}$ Evelin, Hartini. Teori Belajar dan Pembelajaran (Bogor: Ghalia Indonesia, 2014), 82-84.

22 DePorter, Bobi. Quantum Teaching (Bandung, Mizan, 2004), 5-9.

23 Pazmino, Robert W. Fondasi Pendidikan Kristen (Jakarta: BPK Gunung Mulia, 2012), 297-300.

${ }^{24}$ Sumadi, S. Psikologi Pendidikan (Jakarta: Raja Grafindo Persada, 2014), 192-194. sebagai masa intelektual. d.) usia 13- 20 sebagai masa sosial24. Konsep kreatifitas pengajar adalah terfokus pada apa yang sedang dilakukan murid-muridnya, sesuai periodisasi usia 7,0-13 adalah intelektual, dengan tujuan mengajarkan cara berpikir, merentangkan pikirannya (Mark. 4), perumpamaan tentang penabur. Hal yang digambarkan oleh Yesus adalah penabur dan benihnya sama, namun tergantung pada tanahnya. Berikutnya adalah mengajari murid cara belajar, dan akhirnya mengajari murid cara bertindak. ${ }^{25}$ Pada periode ini anak dapat diajak untuk mengingat pangalaman masa lampau dan menggambarkan masa depan untuk merajut cita-cita dan rencana kedepannya. Dalam hal ini, eksistensi dari seorang anak ditentukan oleh kualitas herediter, pengalaman proses belajar dan tujuan yang ingin dicapainya ${ }^{26}$. Dari sisi perkembangan iman, menurut James Fowler ${ }^{27}$ melakukan doa dalam kehidupan seharihari; menerapkan Alkitab dalam kehidupan sehari-hari; menjalin persahabatan kristiani; melakukan penyembahan bersama; menjalankan tanggungjawab untuk melayani Allah; memiliki pengetahuan dasar tentang Allah, Yesus, Roh Kudus, ciptaan, malaikat, surga, neraka, keselamatan, sejarah Alkitab dan literatur Kristen, agar muridmemelihara ajaran dan tidak melupakan ajaran Tuhan sebagaimana yang tertulis dalam Amsal 3:1.

25 Howard, G. Hendriks. Mengajar untuk Mengubah Hidup (Yogyakarta: Yayasan Gloria, 2016), 54-59.

26 Kartini Kartono. Psikologi Anak. (Bandung: Mandar Maju, 1995), 5-7.

27 Robert W. Pazmino. Fondasi Pendidikan Kristen (Jakarta: BPK Gunung Mulia, 2012), 297-300. 


\section{Kesimpulan}

Sekolah Minggu merupakan salah satu fasilitas untuk mengenalkan anak agar memiliki iman dan percaya pada Tuhan. Masa anak-anak merupaka periode yang ideal untuk tetap beriman kepada Tuhan sampai dengan dewasa. Ditengah perkembangan jaman modern ini, maka pendekatan Student Centered Learning (SCL) pada Sekolah Minggu dapat diterapkan, melalui pemahaman keratifitas dan guru terhadap periode tahapan perkembangan anak yaitu:

1. Anak dari usia 0-7 tahun memiliki kepekaan motoris dan kepekaan terhadap moral, dimana pada kisaran usia tersebut masuk pada tingkat prekonvensional, dapat dikenalkan tentang ketaatan kepada Allah, memiliki iman intuitif-projektif, dapat memahami kasih, rasa aman, disiplin, sukacita dan penyembahan kepada Tuhan.

2. Pendekatan SCL yang dapat dilakukan secara kognitif dikategorikan dalam ranah knowledge, mengingat, menghafal informasi, pengetahuan, dan Comprehension, memahami informasi dan dapat menerangkan dengan kalimat sendiri, serta aplication, mengaplikasikan arti ketaatan. Secara afektif masuk ke ranah receiving yaitu penerimaan, sadar akan adanya suatu nilai, ingin menerima nilai dan responding yaitu respons aktif berpartisipasi. Secara psikomotorik menggunakan benda/alat/simbol untuk melatih motorik.

3. Anak dari usia 7-12 tahun, secara perkembangan iman mythic-literal, pada masa akhir kanak-kanak seorang anak biasanya mempercayai sesuatu yang dipercayai orang tuanya dan tidak pernah yang lain, memahami belajar secara aktif untuk membagikan pengalaman serta dialog, atau dengan bermain peran dalam bentuk sandiwara bahkan menjadi reporter.

4. Implementasi SCL dapat dikembangkan untuk mendorong murid secara kognitif, masuk ke ranah analisis, tentang informasi yang dibagikan oleh teman-temannya dalam bentuk cerita sederhana, dan syntesis, yaitu mengombinasikan secara sederhana terhadap pengalaman dari dirinya serta evaluation, yaitu membuat penilaian terhadap pengalaman yang diceritakan tersebut. Secara afektif adalah diarahkan ke sikap valuing, murid siap menerima nilai-nilai, tunduk pada nilai-nilai tertentu; organizing murid dapat menata dan menghubung-hubungkan nilai-nilai yang diyakininya, serta characterizing yaitu murid mulai menyikapi karakterisasi nilai yang akan dijadikan bagian nilai-nilai dari pola hidupnya. Secara psikomotorik dapat diarahkan melakukan gerakan presisi, melakukan gerakan yang tepat atau akurat; artikulasi, yaitu memberikan sentuhan seni dengan menggabungkan beberapa hal yang menghasilkan sebuah harmoni.

\section{Referensi}

Amy Iwani. Belajar dari Sang Guru Agung Sebagai Kurikulum Hidup. Surabaya: MPK, 2016.

Boehlke, Robert R. Sejarah Perkembangan Pikiran dan Praktek Pendidikan Agama Kristen. Jakarta: BPK Gunung Mulia, 2016.

Cully, Iris V. Dinamika Pendidikan Kristen. Jakarta: BPK Gunung Mulia, 2011.

DePorter, Bobi. Quantum Teaching. Bandung, Mizan, 2004. 
Evelin, Hartini. Teori Belajar dan Pembelajaran (Bogor: Ghalia Indonesia, 2014.

Groome, Thimas H. Christian Religious Education. Jakarta: BPK Gunung Mulia, 2011.

Homrighausen, Enklaar. Pendidikan Agama Kristen. Jakarta: BPK Gunung Mulia, 2015.

Howard, G. Hendriks. Mengajar untuk Mengubah Hidup. Yogyakarta: Yayasan Gloria, 2016.

Isjoni \& Firdaus, LN. Pembelajaran Terkini. Yogyakarta: Pustaka

Pelajar, 2008.

Kartini Kartono. Psikologi Anak. Bandung: Mandar Maju, 1995.

Khoe Yau Tung. Desain Instruksional. Yogyakarta: Andi, 2016.

Khoe Yao Tung. Pembelajaran dan Perkembangan Belajar. Jakarta: Indeks, 2015.

Khoe Yao Tung. Menuju Sekolah Kristen Impian Masa Kini. Yogyakarta: Andi, 2015.

Khoe Yao Tung. Filsafat Pendidikan Kristen. Yogyakarta: Andi, 2013.

Nyoman, Olga. Psikologi Pendidikan I. Jakarta: Erlangga, 2014.

Meilania. Creative Teaching di Sekolah Minggu.Yogyakarta: Gloria Gaffa, 2015.

Pazmino, Robert W. Fondasi Pendidikan Kristen. Jakarta: BPK Gunung Mulia, 2012.

Sumadi. Psikologi Pendidikan. Jakarta: Raja Grafindo Persada, 2014.

https://insightsineducation.info/2016/02/ diunduh 12 Januari 2019 